\title{
The Study of the Electrical Conductivity of Apples and Grapes as an Object of Electrical Processing
}

\author{
Abdurahman Radjabov, Matkarim Ibragimov, and Nodir Eshpulatov* \\ Tashkent Institute of Irrigation and Agricultural Mechanization Engineers, Tashkent, Uzbekistan
}

\begin{abstract}
Experimental studies of the electrical conductivity of whole berries, peels, and pulp of apples and grapes were carried out according to the methods that the measurement voltage should not exceed the threshold and the measurement time should be minimal, and mechanical damage to the cells during contact with the electrodes was not allowed. To study the electrical conductivity (electrical resistance) of apples, grapes, and their constituent elements, a device is developed that represents a three-electrode system. The study of the specific volume resistance of the pulp of apple and grape. Development of a methodology for a three-electrode system to determine the electrical conductivity of the pulp and skin of fruits and grapes. Three-electrode system showed sufficient accuracy for apple and grape the electrical conductivity. The volumetric resistance of the skin was much greater than the pulp. The tissue resistance of fruits and grapes with an increase in the frequency of the measuring current decreases exponentially.
\end{abstract}

Key words: Biological materials, cellular structures, electric current, electrical resistivity.

\section{Introduction}

The practical interest in pulsed electrical processing of biological objects is primarily associated with a non-thermal increase in the permeability of cells in an electric field [1,2]. Dielectric breakdown [3] or called electroplasmolysis [4-6] of biological cells occurs as a result of the formation and growth of pores in cell membranes polarized by an electric field $[7,8]$. In food technologies, pulsed electric processing is used for non-thermal pasteurization of liquid products [2,9] and the intensification of mass transfer processes in plant tissues $[10,11]$. It is proposed to use electroplasmolysis in industries related to the processing of plant materials as an additional method to increase the efficiency of processes such as pressing [12], separation centrifugation [13, 14], extraction [15, 16], osmotic dehydration [17], drying [18, 19]. The effectiveness of these processes is determined by the structural properties of raw materials. Therefore, a change in these properties as a result of electroplasmolysis of plant tissue is an important factor in optimizing the conditions of both the electric processing itself and its combination with other methods of processing raw materials $[11,20]$.

\footnotetext{
${ }^{*}$ Corresponding author: nodir_1885@mail.ru
} 
The nature of electroplasmolysis and pore localization have not been studied yet. The generally accepted mechanism of electrical destruction of suspended cells, such asmicroorganisms and red blood cells, is the formation of pores in the lipid matrix of cell membranes [21]. Electroplasmolysis of cells of biological tissues (plant and animal) can also be explained by electroporation of cell membranes [11] and violation of the integrity of cell walls [22]. In this case, the plasmolysis of cells proper is observed, accompanied by leakage of juice from cell wall and a decrease in the volume of vacuole [23, 24]. However, the mechanism of the influence of the electric field on the cell walls is poorly understood and remains largely unclear.

The measurement of the electrical conductivity of living tissue is carried out at a minimum value of the Alternating Current (AC) potential in a wide frequency range. Moreover, at low frequency, the capacitance during the measurement is very significant. This is primarily due to electrode polarization, which manifests itself as a result of the accumulation of a space charge at the boundary of the electrode with the test substance [25].

Experimental studies of the electrical conductivity of the whole berry, peel, and pulp of apples and grapes were carried out according to existing methods [26-28], taking into account that the measurement voltage should not exceed the threshold and the measurement time should be minimal, and mechanical damage to cells upon contact with the electrodes is not allowed.

\section{Material and methods}

To study the electrical conductivity (electrical resistance) of apples, grapes, and their constituent elements, a device was developed that represents a three-electrode system consisting of plate potential and ring electrodes made of stainless steel (Figure 1 and Figure 2).

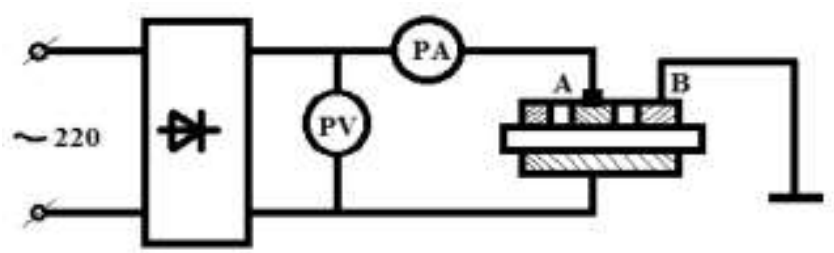

Fig. 1. Schematic diagram of the stand for measuring volumetric electrical resistance $\left(\rho_{v}\right)$.

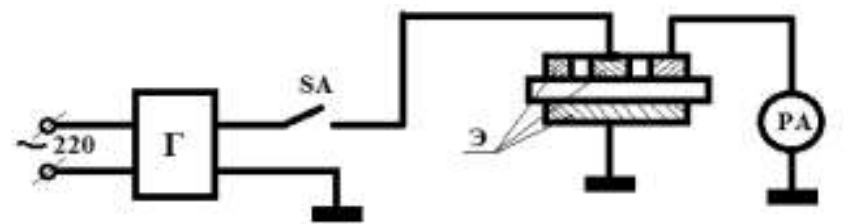

Fig. 2. Schematic diagram of the stand for measuring surface resistance $\left(\rho_{s}\right): \Gamma-$ signal generators GZSh-33; SA - switch; Э - electrodes; PA - milliammeter; $\mathrm{O}$-sample.

The experiments were carried out as follows. A sample was cut from an apple into the shape of a plate and placed between the electrodes. To ensure reliable contact of the electrodes with the surface of the sample, a certain pressure was created from the outside of the electrodes. The pressure force values were determined according to the conditions of maintaining the mechanical integrity of the tissue cell (for example, for grapes $-10000 \mathrm{~Pa}$, for apples $-11000 \mathrm{~Pa}$ ). 
After measuring the biopotential, the voltage was applied to the opposite surfaces of the sample to the electrodes, and every $30 \mathrm{sec}$, the current and voltage were recorded for $7 \mathrm{~min}$. The data of the 6-fold repetition of experiments were subjected to statistical processing by a well-known method [28].

The resistivity was calculated by the Formula (1) and Formula (2)

$$
\begin{aligned}
& \rho_{v}=0,785 R_{v} \frac{d_{c p}^{2}}{h}, \\
& \rho_{s}=\frac{2 \pi R_{s}}{\ln \frac{d_{2}}{d_{1}}}
\end{aligned}
$$

Note: $d_{c p}=\frac{d_{1}-d_{2}}{2}$

$d_{1}$ - diameter of a measuring electrode, $\mathrm{m}$;

$d_{2}$ - inner diameter of the ring electrode, $\mathrm{m}$;

$h$ - sample thickness;

$\rho_{v}, \rho_{s}-$ bulk and surface electrical resistance of the sample.

\section{Result and discussions}

Initial studies were carried out at constant current according to the circuit shown in Figure 1. According to the results of measurements and calculations, dependencies are obtained that characterize the measurement of the specific volume resistance of the pulp of apple and grape. Figure 3 and Figure 4 show the patterns of change in the pulp of apples of the "Semerenko" variety from the gradient, the applied voltage, and the duration of its exposure.

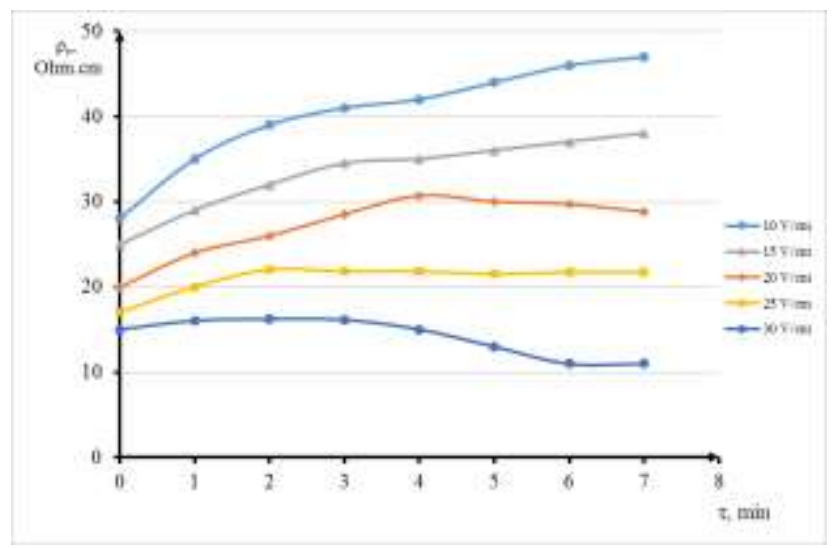

Fig. 3. The dependence $\rho_{v}$ of the pulp of apples "Semerenko" on the duration and impact of direct current at various values of the gradient of the applied voltage.

The dependencies of Figure 3 showed the specific volume resistance of the pulp at gradients of the applied voltage of $10 \mathrm{~V} \mathrm{~cm}^{-1}$ to $20 \mathrm{~V} \mathrm{~cm}^{-1}$ in the initial period increases and approaches the steady-state value for $7 \mathrm{~min}$, and more measurements. Such a pattern is associated with electrode polarization, which leads to a decrease in the potential at the electrodes at the initial time of measurement. At gradients of the applied voltage of 
$20 \mathrm{~V} \mathrm{~cm}^{-1}$ to $25 \mathrm{~V} \mathrm{~cm}^{-1}$, the steady-state resistance value is reached faster (within $4 \mathrm{~min}$ to $5 \mathrm{~min}$ ), as evidenced by a decrease in the influence of the biopotential and the phenomenon of polarization at the indicated values of the gradient of the applied measurement voltage. With a further increase in the gradient of the applied voltage of $25 \mathrm{~V} \mathrm{~cm}^{-1}$ or more, a constant decrease in the value of resistivity from the initial was observed due to the partial death of tissue cells from the damaging effect of the current as of the measurement duration increases.

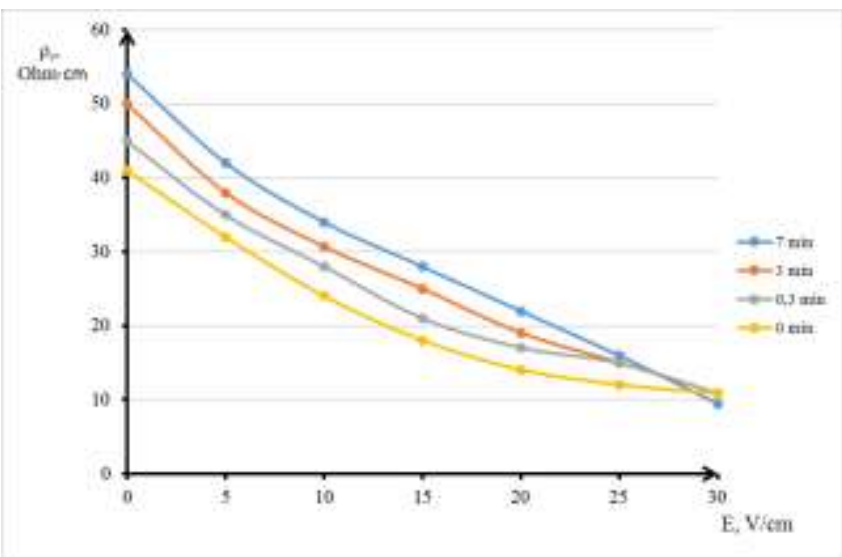

Fig. 4. The dependence $\rho_{v}$ of the pulp of apples "Semerenko" on the gradient of the applied voltage for different duration of exposure.

The analysis of the dependencies in Figure 4 also indicates that measuring the volumes of resistance of the pulp of the tissue with gradients of the applied voltage of $20 \mathrm{~V} \mathrm{~cm}^{-1}$ to $25 \mathrm{~V} \mathrm{~cm}^{-1}$ gives more accurate results with a minimum measurement time.

Due to the fact that the new technology provides for the impact on the fruits and grapes of pulsed electrical discharges, and also consider the relatively long duration of measuring the resistance to direct current, the patterns of change in the electrical resistance of the electric processing object (fruits, grapes, and their constituent elements) using alternating current the circuit shown in Figure 2.

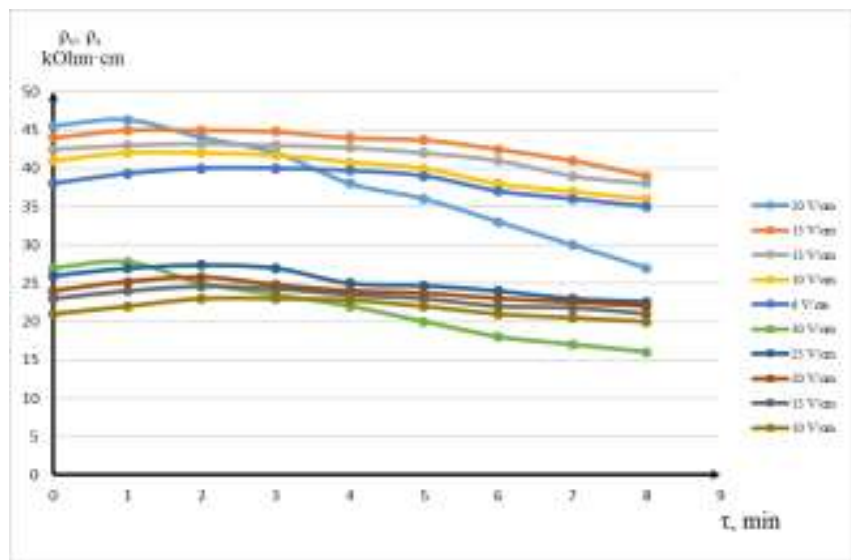

Fig. 5. Dependence $\rho_{v}, \rho_{s}$ of apple pulp ("Rosemary") on the time of exposure to an electric current with a frequency of $1000 \mathrm{~Hz}$ at various gradients of the applied voltage. 


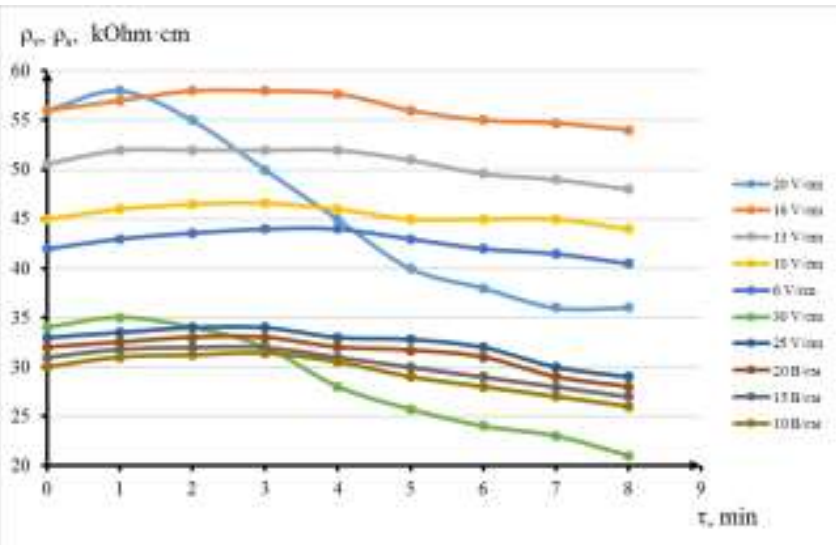

Fig. 6. Dependence $\rho_{v}, \rho_{s}$ of grape flesh on the time of exposure to an electric current with a frequency of $1000 \mathrm{~Hz}$ at different gradients of the applied voltage.

An analysis of the curves of the dependences $\rho_{v}$ and $\rho_{s}$ on the time of exposure to an electric current of variable frequency $(\mathrm{f}=1000 \mathrm{~Hz}$ ) at various gradients of the applied voltage (in Figure 5 - the pulp of the apple, in Figure 6 - the pulp of the grape) shows that the gradient of the applied voltage at measurement $\rho_{v}$ should not exceed $25 \mathrm{~V} \mathrm{~cm}^{-1}$, and measurement $\rho_{s}-15 \mathrm{~V} \mathrm{~cm}^{-1}$. an increase in the gradient of the applied voltage of the indicated values distorts the true value of the resistance.

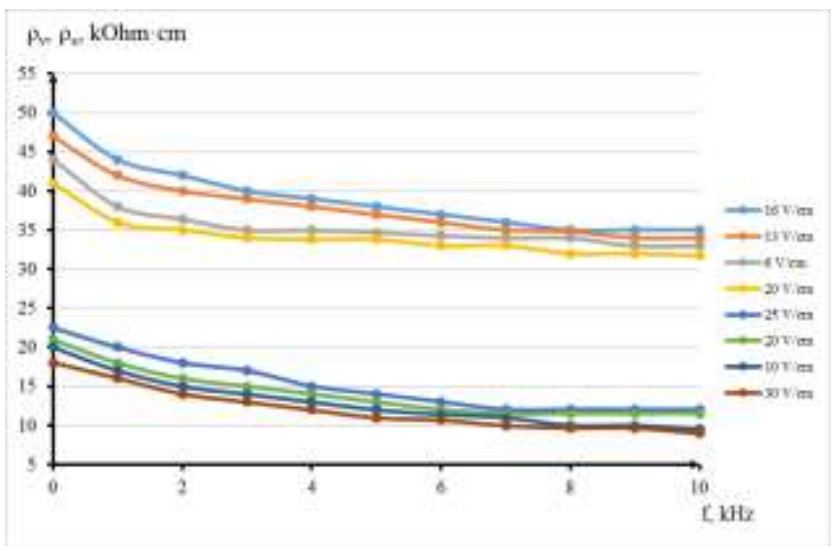

Fig. 7. Dependence $\rho_{v}, \rho_{s}$ of the Rosemary apple on the frequency of the current at various gradients of the applied voltage. 


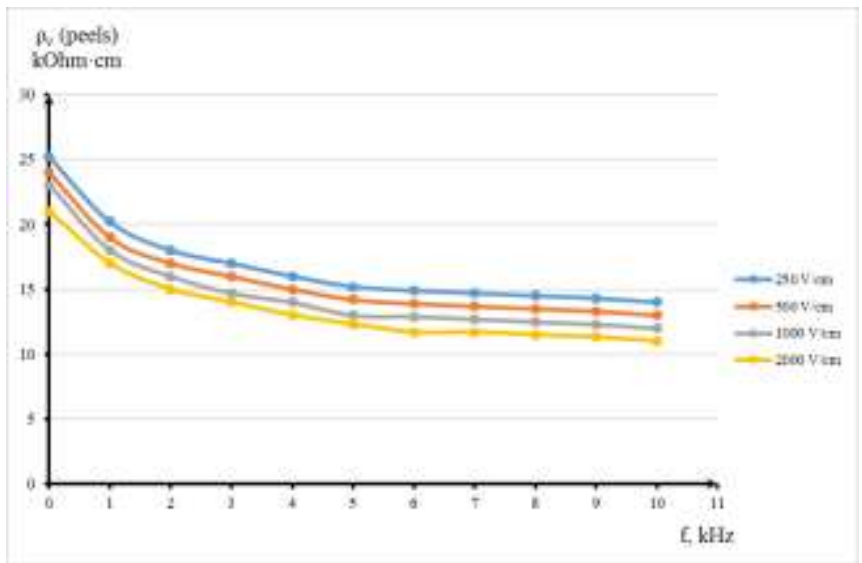

Fig. 8. Dependence $\rho_{v}$ (peel) of the Rosemary apple on the current frequency at various gradients of the applied voltage.

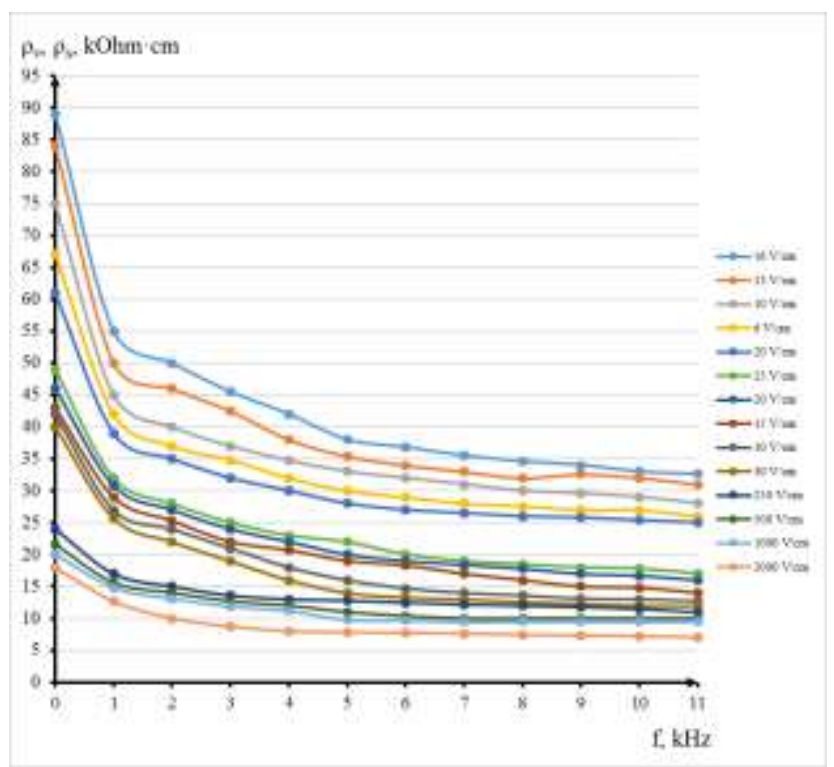

Fig. 9. Dependence $\rho_{v}, \rho_{s}$ of pulp and $\rho_{v}$ peel of "Tayfi" grape skin on current frequency at various gradients of applied voltage.

Based on the results of studying the changes $\rho_{v}$ and $\rho_{s}$ of the pulp of apple and grapes and $\rho_{v}$ of their peel on the frequency of the measuring current for various values of the applied voltage gradient, the relationship between them in the form of graphical dependencies shown in Figure 7, Figure 8, and Figure 9. With increasing frequency of the measuring current, both volumetric $\rho_{v}$ and surface resistance of the pulp $\rho_{s}$ and volumetric resistance of the skin $\rho_{v}$ decrease exponentially at a frequency of $5 \mathrm{kHz}$ to $10 \mathrm{kHz}$ and reaches a constant value. In addition, the volumetric resistance of the skin $\rho_{v}$ 
must be measured at gradients of the applied voltage two orders of magnitude more than when measuring $\rho_{v}$ and $\rho_{s}$ the pulp.

\section{Conclusion}

i. The developed private technique and the three-electrode system make it possible to determine with sufficient accuracy the values of the electrical conductivity of the pulp and skin of fruits and grapes.

ii. The gradient of the applied voltage to the test sample should not exceed the threshold value of the damage to living cells (when measuring $\rho_{v}$ and $\rho_{s}$ the pulp, respectively, no more than $20 \mathrm{~V} \mathrm{~cm}^{-1}$ and $10 \mathrm{~V} \mathrm{~cm}^{-1}$ and $\rho_{v}$ the skin no more than 1 $\left.000 \mathrm{~V} \mathrm{~cm}^{-1}\right)$.

iii. The volumetric resistance of the skin is much greater than the pulp, which is due to a denser arrangement of cells of its tissue.

iv. The tissue resistance of fruits and grapes with an increase in the frequency of the measuring current decreases exponentially, which indicates its additivity with the impedance of the resistance of plant materials.

\section{References}

1. D. Knorr, A. Angersbach. Trends Food Sci. Technol. 9,5:185-191(1998).

2. G.V. Barbosa-Canovas, M.D. Pierson, Q.H. Zhang, D.W. Schafner. Pulsed electric fields. J. Food Sci. 65,(supplement):65-79(2000).

3. U. Zimmermann, G. Pilwat, F. Beckers, F. Rieman. Effects of external electric fields on cell membranes. Bioelectrochem. Bioenerg. 3:58-83(1976).

4. M.R. McLellan, R.L. Kime, L.R. Lind. Electroplasmolysis and other treatments to improve apple juice yield. J. Sci. Food Agric. 57:303-306(1991).

5. M. Gudmundsson, H. Mafsteinsson. Effect of electric field pulses on microstructure of muscle foods and roes. Trends Food Sci. Technol. 12:122-128(2001).

6. ЛазаренкоБ.Р., ФурсовС.П., ЩегловЮ.А. идр. Электроплазмолиз. Кишинев, (1977).

7. M. Winterhalter, W. Helfrich. Effect of voltage on pores in membranes. Phys. Rev. A. 36,12:5874-5876(1987).

8. J. Teissie, N. Eynard, B. Gabriel, M.P. Rols. Electropermeabilization of cell membranes. Advanced Drug Delivery Rev. 35:3-19(1999).

9. L. Barsotti, E. Dumay, T.H. Mu, M.D.F. Diaz, J.C. Cheftel. Effects of high voltage electric pulses on protein-based food constituents and structures. Trends Food Sci. Technol. 12:136-144(2001).

10. И.С. Гулый, Н.И. Лебовка, Манк В.В. и др. Научные и практические принципы электрической обработки пищевых продуктов и материалов. Киев, (1994).

11. B.I.O. Ade-Omowaye, A. Angersbah, K.A. Taiwo, D. Knorr. Use of pulsed electric field pretreatment to improve dehydration characteristics of plant based foods. Trends Food Sci. Technol. 12,8:285-295(2001).

12. M.I. Bazhal, E.I. Vorobiev. Electrical treatment of apple slices for intensifying juice pressing. J. Sci. Food Agric. 80:1668-1674(2000).

13. T. Beveridge. Juice extraction from apples and other fruits and vegetables. Critical Rev. Food Sci. Nutr. 37,5:449-469(1997). 
14. D. Knorr, A. Angersbach, M.N. Eshtiaghi, V. Heinz, D.U. Lee. Processing concepts based on high intensity electric field pulses. Trends Food Sci. Technol. 12,4:129135(2001).

15. A.B. Jemai. Contribution al'étude de l'effet d'un traitementélectrique sur les cossettes de betterave a sucre. Incidence sur le procéded'extraction. Thése de Doctorat, Université de Technologie de Compiégne, France, (1997).

16. Купчик М.П. Разработка технологии сахара из свеклы с применением электрических полей низкой частоты: Автореф. дис. докт. техн. наук. М., (1991).

17. N.K. Rastogi, N.M. Eshtiaghi, Knorr D. Accelerated mass transfer during osmotic dehydration of high intensity electrical field pulse pretreated carrots. J. Food Sci. 64,6:1020-1023(1999).

18. B.I.O. Ade-Omowaye, A. Angersbah, N.M. Eshtiaghi, D. Knorr. Impact of high intensity electric field pulses on cell permeabilisation and as pre-processing step in coconut processing. Innovative Food Sci. EmergingTechnol. 1,3:203-209(2000).

19. Б ордиян В.В., Интенсификация сушки растительного сырья электроплазмолизом: Автореф. дис. канд. техн. наук. М., (1991).

20. M.I. Bazhal, N.I. Lebovka, E.I. Vorobiev. Pulsed electric field treatment of apple tissue during compression for juice extraction. J. Food Eng. 50,3:129-139(2001).

21. J.C. Weaver, Y.A. Chizmadzhev. Theory of electroporation: a review // Bioelectrochem. Bioenerg. 41:135-160(1996).

22. A.M. Rojas, M.A. Castro, S.M. Alzamora, L.N. Gershenson. Turgor pressure effects on textural behaviour of honeydew melon // J. Food Sci. 66,1:111-117(2001).

23. Чебану В.Г. Повышение эффективности электроплазмолиза растительного сырья: Автореф. дис. канд. техн. наук. Киев, (1987).

24. M. Fincan, P. Dejmek. In situ visualization of the effect of a pulsed electric field on plant tissue // J. Food Eng. 55,3:223-230(2002).

25. Капилов Ю.А., Еськов-Сосковец В.М. Основные направления в создании оборудования с использованием электрофизических методов обработки пищевых продуктов. - М., (1976). - С.39.

26. N.M. Eshpulatov. Intensification of withdrawing process of juice using of electrotechnological methods. Актуальные проблемы аграрной науки, производства и образования. Материалы ІІмеждународной заочной научнопрактической конференции молодых ученых и специалистов на иностранных языках. Россия, Воронеж, апрель (2016) г. 283-288 с.

27. Н.М. Эшпулатов, М.Н. Саломов. Электротехнологические методы повышения энергоэффективности в производстве соков плодов и винограда. Приоритетные направления развития современной науки молодых учёных аграриев. Материалы V-ой Международной научно-практической конференции молодых ученых, посвященные 25-летию ФГБНУ «Прикаспийский НИИ аридного земледелия». с. Соленое Займище 11-13 мая (2016) г. 784-787 с.

28. Раджабов А. Методологические основы энергосберегающей электротехнологии сушки плодов и винограда. Автореф. док. дисс. - Челябинск, (1991). — 36 с. 